\title{
EFFECT OF FINANCIAL KNOWLEDGE AND SKILLS ON THE FINANCIAL SUSTAINABILITY OF AFFIRMATIVE GROUPS IN KAPSERET SUB COUNTY
}

\author{
Sharon Ayoma Kweno ${ }^{1}$, Mwengei K. B. Ombaba ${ }^{2}$ \\ ${ }^{1}$ MBA Finance, Jomo Kenyatta University of Agriculture and Technology \\ ${ }^{2}$ Lecturer, Jomo Kenyatta University of Agriculture and Technology
}

DOI: 10.46609/IJSSER.2020.v05i10.021 URL: https://doi.org/10.46609/IJSSER.2020.v05i10.021

\begin{abstract}
The government has the responsibility to alleviate poverty and empower the deprived women, youth and persons with disability in accessing loan facilities and starting their own income generating activities. The affirmative groups introduced by the government of Kenya include the youth enterprise fund, women enterprise fund and uwezo fund. Financial sustainability of affirmative groups is important as it determines the sustainability of the funds. The current study sought to determine the effect of financial knowledge and skills on the financial sustainability of affirmative groups. The study considered the Grameen bank model and resource based theory theories to underpin the study. A cross sectional research design was adopted. The target population is 400 affirmative funded groups. The sample size is 200 affirmative funded groups. Stratified random sampling and simple random sampling were used to select the respondents. Primary data was collected using structured questionnaires. Content validity and internal consistency reliability was adopted. Data analyzed was presented using descriptive statistics and inferential statistics. The study findings indicated that financial knowledge and skills has a positive and significant effect on financial sustainability of affirmative groups in Kapseret Subcounty, Uasin Gishu. This study recommends that the management of the affirmative groups to ensure that financial skills and knowledge is paramount in to enhance financial sustainability among affirmative groups. The study will be of great benefit to policy makers of Kapseret sub county government in development of policies on financial sustainability of affirmative groups.
\end{abstract}

Key words: Financial Knowledge and Skills, financial sustainability, affirmative groups

\section{Background of the Study}

The government has a responsibility to alleviate poverty and empower the deprived women, youth and persons with disability in accessing loan facilities and starting their own income 


\section{International Journal of Social Science and Economic Research}

ISSN: $2455-8834$

Volume:05, Issue:10 "October 2020"

generating activities. Governments have come up with affirmative groups for empowerment of the marginalized in the society in regards to accessibility to employment opportunity and loan facilities (Sagwe, Gacheru, \&Mahea, 2011). According to Mungai (2009), the affirmative groups which include large percentage of the youth, women and persons with disability will be able to benefit if government and other lenders adopts lending conditions that are flexible to the borrowers, hence reducing default rates and improving financial sustainability of the affirmative groups.

Financial sustainability of the affirmative groups is measured by the number of the funded groups who are able to access the fund and repay it on a stipulated period without delay in order to extend further benefits to other needy groups (Muli, 2016). High nonperforming loan ratio, delays on repayment, lack of training and lack of monitoring of group projects may lead to financial unsustainability affirmative groups. According to Njuguna (2014), the level of education, management practices, lending conditions, entrepreneurial competencies and demographic factors influence the financial sustainability of affirmative groups. Bank Finland Plc's annual report and corporate governance report's (2009) stipulates that savings structure, business plan, credit history, membership profile influences the financial sustainability of any affirmative groups. Oboh and Ekpebu (2011) posit that when loan allocation is efficiently managed, government funds will have a better sustainability.

Financial knowledge and skills is the ability to understand and effectively apply various financial skills, including personal financial management, budgeting, and investing. It helps individuals become self-sufficient so that they can achieve financial stability (Abraham, 2006).The prerequisites of financial knowledge and skills that groups must possess before the loan product is extended to them includes financial planning skills, business skills, book keeping knowledge and credit management skills among others. Financial knowledge and skills is effective in reducing borrower defaults (De Aghion, 2009). In group lending, the loan is secured by the cosignature of members within the group. Group sanction is important in discouraging defaults among members in microfinance (Van Tassel, 2009). In order to achieve effective financial sustainability of affirmative groups the management of affirmative groups should be able to vet every group through determining the viability of the project and also to determine the competence of every member in regard to financial knowledge and skills towards management of acquired loan.

\section{Global Perspective on Financial Sustainability of Affirmative Groups}

Globally, many countries have come up with different affirmative groups to empower the youth and women to start their own business. The youth enterprise fund among other funds is widely used initiatives by many governments to promote youth employment and a key driver to the 


\section{International Journal of Social Science and Economic Research}

ISSN: 2455-8834

Volume:05, Issue:10 "October 2020"

economic growth. The Canadian Youth Business Foundation which was meant for the unemployed and underemployed to design youth business loan program specifically tailor made for which was established in 1996 (Karlan\&Morduch, 2009). Over the years higher loan default rates have been reported hindering the sustainability of the program which was meant to empower the youth and improve economic growth. The high default rate is attributable to inflexible repayment frequency that did not favor the volatility in the business life cycle.

In Britain, the Prince's Trust Enterprise Program (PTEP) is for people who have a business idea they want to exploit and aged between 18 and 30 years, unemployed or working less than 16 hours per week. Services provided include advice on employment options, start-up loan funding, ongoing support from a volunteer business mentor, access to specialist support including free legal services and also access to wide range of free and discounted products and services (The Prince's Trust, 2012). Sustainability of the fund has been compromised by adverse lending conditions that have adversely affected the loan repayment status.

In Bangladesh, Yunus founded group lending in the 1980's. the fund was meant to assist vulnerable groups like youth groups and women groups who could not access capital to either start or boost their small businesses due to lack of security. The group funding in Bangladesh there has been reduced repayment burden due to lower interest rates amongborrowers which in turn reduced repayment burden (Hermes et al., 2005). Group lending in Bangladesh has grown exponentially since 1983 and is viewed as a revolutionary tool for global poverty alleviation (Yunus, 1999). The rise in prominence is attributed to the joint-liability lending model pioneered by Grameen Bank whereby traditional lender requirements for physical collateral are bypassed through mutual responsibility for individual loans. Municipal government funds, financing green growth fund all in Bangladesh have evolved to cater for the needs of the less privileged by adopting group lending as a means to access funds which has ensured there is a better sustainability of affirmative groups in Bangladesh.

\section{Regional Perspective on Financial Sustainability of Affirmative Groups}

In Ghana, few employment options are available and many young men and women leave their villages for urban centres. This migration leads to an ageing and generally less dynamic population in rural areas, with high rates of youth unemployment, underemployment and social inequality. This prompted the government to initiate IFAD loans so as to support the reduction of poverty in line with the government's economic development strategy. IFAD-supported projects help build inclusive and sustainable institutions, backed by pro-poor investments and policies and relevant innovation and learning (Ayogyam, 2014). The state through the ministry of youth, requested the youth to form groups so as to access the funds. The researchers' note that as much as loans were extended to the youth, for the last three decades, loans default rates have increased 


\section{International Journal of Social Science and Economic Research}

ISSN: $2455-8834$

Volume:05, Issue:10 "October 2020"

as a result of inflexible lending conditions that did not factor in changes within the business environment that affects cash flows of a business.

According to a report by ILO (2012), in Botswana, out of school youth fund was established in 2001 to diversify the economy. The out of school fund was introduced in the 2009/2010 financial year as a 50\% grant and 50\% loan scheme to encourage the out of school, marginalized and unemployed youth to venture into sustainable and viable income generating projects. The permanent secretary ministry of youth empowerment, sports and culture development revealed that the youth development fund is owed approximately P400 million in uncollected loan repayments from groups. The high rate of default rate of the affirmative groups was attributed by unfavorable lending conditions which included unviable business model, lack of cohesiveness, and lack of entrepreneurial skills in the borrowing groups.

In Nigeria, the Nigeria Trust Fund was created in 1976 by agreement between the Bank Group and the Nigerian government. It is a self-sustaining affirmative groups. Concessional financing is done to regional member countries whose economic and social need development efforts. The fund has been extended to so many low income countries over two decades. Delinquency and Loan default rates have been recorded over the years (Udoh, 2018). Also, in Nigeria, 75 percent of government sponsored loans disbursed by AkwaIbon State Agricultural Loan Board to farmers, 59 percent were loan defaulters which is attributed to repayment frequency that doesn't favor the borrowers earnings due to unpredictable earning thus affecting the financial sustainability of the group.

\section{Kenyan Perspective on Financial Sustainability of Affirmative Groups}

In Kenya, the government has introduced various affirmative groups to facilitate achievement of improving livelihoods and foster social and economic equity in the population and regions. These funds include Youth Enterprises Development Fund, Women Enterprises Development Fund and the Uwezo Fund among others (Kimathi, 2012). The Ministry of Public Service, Gender and Youth Affairs is a state corporation which hosts the Youth Enterprise Development Fund (YEDF) and was gazetted on 8th December 2006 and then transformed into a State Corporation on 11th May 2007. The strategic focus of the fund which is one of the projects flagged under the social pillar of vision 2030 is on enterprise development as a key strategy that will increase economic opportunities for, and participation by Kenyan Youth in nation building.

The Fund seeks to create employment opportunities for young people through entrepreneurship and encouraging them to be job creators and not job seekers. It does this by providing easy and affordable financial and business development support services to youth who are keen on starting or expanding businesses (GoK, 2012). The fund was to target 13 million youths aged between 18 to 35 years in Kenya. The development of YEDF came as a result of various complaints of 


\section{International Journal of Social Science and Economic Research}

ISSN: $2455-8834$

Volume:05, Issue:10 "October 2020"

neglecting of the youths overtime. The complaints have gained a lot of support from the public, since the population of women and the youths has been growing at a very high rate, and employment opportunities have not matched to that growth (Sagwe et al., 2011).

Women Enterprise Fund is an affirmative fund groups initiated by the government of Kenya through the legal notice No. 147, the government financial management (Women Enterprise Fund) Regulations in 2007. The mandate of the Fund is to provide subsidized credit to women entrepreneurs for enterprise development. Capacity building is done to women entrepreneurs and their organizations in order to attract and facilitate investment in micro, small and medium enterprises oriented infrastructure such as business markets or business incubators that will be beneficial to women enterprises. Support women oriented micro, small and medium enterprises to develop linkages with large enterprise. Facilitate marketing of products and services of women enterprises in both domestic and international markets (GoK, 2012).

The Uwezo Fund is a programme that ensures women, youth and persons with disability access finances at the sub county level hence promoting their businesses and enterprises thereby enhancing economic growth towards the realization of the Millennium Development Goals. The Fund was launched by His Excellency the President of the Republic of Kenya, Uhuru Kenyatta, on 8th September 2013 and enacted through a Legal Notice No. 21 of the Public Finance Management Act, 2014, and published on 21st February, 2014 (Olima, 2016). Uwezo Fund is available to women and youth groups and is distributed at the sub county level. The fund is administered through the Sub county Uwezo Fund Management Committees who oversees implementation of the fund in all 290 constituencies in Kenya (Otieno, 2014). The financial sustainability of the affirmative groups solely depends on the sustainability of the funds. Repayment of the fund by the groups will make funds to be available for others to benefit from it too.

According to the Auditor general's report (2017), the affirmative groups have not reached the targeted number of groups despite a disbursement of more than Sh7 billion. The report further indicated that regardless of the many groups that received soft loans from either the youth enterprise fund, women enterprise fund or the Uwezo Fund many have defaulted on paying back the amounts within stipulated time or failed to pay thus inhibiting sustainability of the affirmative groups (Bwayo, 2017). Kapseret sub county is among the constituencies in Kenya that have been faced by high default rate of the affirmative groups with 45 per cent of the groups yet to remit back the funds to enable other deserving groups get access to the affirmative groups.

The high default rates in Kapseret sub county has been largely attributed to unfavorable lending conditions that has become an impediment towards access of the different affirmative groups and also limiting ability of different groups ability to pay back the loan (Muthoni, 2016). 


\section{International Journal of Social Science and Economic Research}

ISSN: $2455-8834$

Volume:05, Issue:10 "October 2020"

According to the affirmative groups chairperson in Kapseret Sub County (2018), regardless of disbursement of nine million shillings there is low uptake of Youth Enterprise Fund, Women Enterprise Fund and Uwezo Fund due to infringement to group funding initiatives, inflexible loan repayment plans. Youth enterprise fund, women enterprise fund and Uwezo enterprise fund repayment sustainability is low in Kapseret Sub County with the default rates are 35\%, 26.4\% and $45 \%$ respectively.

\subsection{Statement of the Problem}

The birth of affirmative groups in Kenya was meant to empower the marginalized in the society in regards to accessibility to employment opportunity and loan facilities. The ability of the fund to benefit more people depends on its repayment sustainability. The financial sustainability of affirmative groups depends on repayment sustainability of the groups. The government of Kenya came up with various credit schemes in view of empowering youth, women and PWD. Such schemes are Youth Enterprise Fund, Women Enterprise Fund and recently the Uwezo fund which was launched to bridge the gap between women and the youth who been deprived of credit. Financial sustainability of the affirmative groups is key in ensuring all these needy groups access credit. The rate of nonperforming loans is high and hence an impediment to the financial sustainability of affirmative groups. In January 2019, the Ministry of Public Service, Sports and Gender has blacklisted Tana River County from benefiting from Uwezo Fund following massive default (Odour, 2019). The massive default recorded is due to infringement to group funding initiatives, inflexible loan repayment plans as opined by (Oduor, 2019). According to the affirmative group's chairpersons in Kapseret Sub County, there is low uptake of Youth Enterprise Fund, Women Enterprise Fund and Uwezo Fund. Youth enterprise fund, women enterprise fund and Uwezo enterprise fund repayment sustainability is low, the default rates are $35 \%, 26.4 \%$ and $45 \%$ respectively. There is low uptake of loan by affirmative groups and defaulted on repayment of the fund and hence adversely affected the overall sustainability of the fund groups. Most of the studies that have been conducted on affirmative groups for example, Mungai (2018) researched on Loan repayment and sustainability of government affirmative groups in Murang'a County. The study's scope did not incorporate the effect of group funding and repayment plans on financial sustainability of affirmative groups which the current study seeks to incorporate. Therefore this study seeks to determine the effects of lending conditions on the financial sustainability of affirmative groups in Kapseret Sub County in UasinGishu County.

\section{Objective of the Study}

To evaluate the effect of financial knowledge and skills on the financial sustainability of affirmative groups in Kapseret Sub County.

\section{Hypothesis of the Study}




\section{International Journal of Social Science and Economic Research}

ISSN: $2455-8834$

Volume:05, Issue:10 "October 2020"

$\mathbf{H}_{01}$ : Financial knowledge and skills has no significant effect on financial sustainability of affirmative groups in Kapseret Sub County.

\subsection{Literature Review}

\section{Theoretical Review}

This study will be guided by the theory of Grameen Bank model and resource based theories.

\section{The Grameen Bank Model}

The theory was founded by Yunus in the 1980's in Bangladesh. The aspect of group lending was introduced in the 1980s by the Grameen Bank in Bangladesh (World Bank, 2009). Joint lending, also known as group liability refers to the conditions of the actual credit contract, whereby individuals are both borrowers and simultaneously guarantors of other clients' loans in the same credit group (Armendariz\&Morduch, 2005). Proponents of group lending argue that the model improves on repayment rates by providing incentives for peers to screen, monitor and enforce each other's loans (Hermes, Lensink, \&Mehrteab, 2005). The contract is aimed at reducing monitoring and enforcement costs and thus allowing lower interest rates among borrowers. These lower rates should reduce the repayment burden and result in less credit rationing (Hermes et al., 2005).

The model tries to explain behavior of individual borrowers who when given access to credit, they will be able to identify and engage in viable income-generating activities. Improvement payments foster group ability to borrow with the ultimate goal of improving groups' liquidity and consequently enhancing the MSEs' growth (Wheelan, 2009). The competency of members of a group in terms of financial knowledge and skills. When borrowing interest rates are low it helps to improve on the profits of the MSEs and ultimately aid in the financial growth of the same. The joint liability has been argued to be better than conventional banks because members of a close knit community may have more information about one another (Hermes et al., 2005).

The group members have been noted to impose powerful non-financial sanctions at low cost (Reavley\&Lituchy, 2008). The introduction of joint liability lending models has achieved its efforts in enabling previously un-bankable or marginalized borrowers as the youth lift themselves up by their bootstraps and create 'social collateral' to replace the missing physical collateral that excluded them from access to more traditional forms of financial services (Hermes et al., 2005). Thus, the emergence of innovative joint liability models in financial intermediation has created new hopes for the poor and marginalized MSEs, which are otherwise un-bankable in the perception of formal financial institutions (Laffont\& Rey, 2013). 


\section{International Journal of Social Science and Economic Research}

ISSN: $2455-8834$

Volume:05, Issue:10 "October 2020"

On the regard to entrepreneurs, group lending approach facilitates access to new ideas, information and resources for business sustainability (Tata \& Prasad, 2008) through social interactions and linkages both within and outside the group. This is becomes an important source of social capital which has been known to positively affect MSEs' development (Wilson et al., 2007; Reavley\&Lituchy, 2008). Ghatak (2000) noted that the borrowers' use of information about each other's projects can lead to self-selection of group members which is observed to enhance choice of group projects based on member's agreement. The theory is criticized by the opponents to the group lending approach who argue that joint liability may lead to tension amongst the group members and final dropouts and worse cause harm to social capital among members. This has been noted to have adverse effects to SMEs development (World Bank, 2009).

Further, different loan sizes can result in resistance within the group as clients with smaller loans are reluctant to serve as a guarantor for those with larger loans (Laffont\& Rey, 2000). It has been argued that, as groups mature it helps them to improve their knowledge on financial knowledge and skills. Further, members are able typically diverge in their demand for credit and may thus be disillusioned by the group lending structure which observes a graduated growth (Hermes et al., 2005). Such challenges have greatly contributed to the decimal sustainability by the affirmative groups (World Bank, 2010). The affirmative groups encourages group members to know each other well before coming together to form group's failure to which the good and more responsible members of the group will have a burden of responsibilities and obligations of the less responsible members.

This requirement has been a tall order for many groups intending to benefit from the affirmative groups given the varied nature of individual differences and competing interests. This approach is heavily relied on by the affirmative groups. All loans given by the affirmative groups are anchored on joint liability model by the members of the beneficiary groups (Affirmative groups, 2012). The application of the theory in this study is to address the financial knowledge and skills objective in group lending perspective.

\section{Financial Knowledge and Skills and Financial Sustainability of Affirmative Groups}

Lilay, Desta and Wondmagegn (2015) researched on the effect of financial knowledge on financial sustainability of affirmative groups' in Ethiopia. The aim of this study was to identify and analyze whether financial knowledge had effect on the financial sustainability of affirmative groups in Ethiopia. This study applied explanatory research approach, cross-sectional primary data, stratified sampling techniques and finally employed chi-square test to test the association of the independent variables and loan repayment sustainability. The researchers found that financial knowledge had a significant effect on financial sustainability of affirmative groups in Ethiopia. 


\section{International Journal of Social Science and Economic Research}

ISSN: $2455-8834$

Volume:05, Issue:10 "October 2020"

Postelnicu, Hermes, and Servin (2019) examined external social ties and loan repayment of group lending members of Pro Mujer in Mexico. The study aimed at establishing whether external social ties had effect on loan repayment. The resources in external ties were measured in conditions of the informal risk insurance arrangement they embed. The extent to which social networks of group members are overlapping is used to extend external ties as collateral. Further, the more borrowers' networks of external ties overlap, the higher the risk of losing the informal risk insurance arrangement in case of non-repayment. The study found that group borrowers with external ties, representing a strong informal risk insurance arrangement while at the same time being information channels, have lower repayment problems. Emphasis was not put on the essence of business skills that group members should possess which the current study seeks to incorporate.

Asgedom, Desta, and Bahita (2015) researched on the effect of financial skills on the sustainability of government based loans in Ethiopia. The objective of the study was to determine how group funding affects government based loans. Primary data was collected from sample respondents (selected by using simple random sampling technique) through questionnaire. Eight seven questionnaires were distributed and 83 (95\% response rate) were collected. The study has applied explanatory type of research. Chi-square test statistics was employed to test the association of each explanatory variable with group loan repayment sustainability (dependent variable). Chi-square test considered 15 explanatory variables. From the findings it was found that financial skills have significant association with loan repayment sustainability.

The study did not incorporate book keeping knowledge as part of the financial knowledge and skills prerequisites.Milgo (2012) assessed the effect of book keeping skills on loan repayments of Youth Enterprise Fund in Kenya. The objective of this study was to establish the effect of book keeping skills on loan repayment rates of youth enterprise fund in Kenya. A causal research design was adopted in the study. The study found out that book keeping skills had a strong positive effect on loan repayment because of financial knowledge and financial information management. Book keeping skills is effective in ensuring timely repayments of funds, instilling supervision and administration traits among the group members. The study concluded that the book keeping skills should be upheld as they ensure increased probability of repayment rates and leads to creation of customer loyalty. Financial planning skills were left out in their study which this study seeks to incorporate.

\section{Conceptual Framework}

The conceptual framework gives the relationship between independent and dependent variables of the study (Luvavo, 2013). The sub indicators of financial knowledge and skills are book 
keeping, business skills, credit management skills and financial planning skills. Financial sustainability of affirmative groups is the dependent variable operationalized using repayment duration, non-performing loan ratio, and refinancing and own income generation. It is hypothesized that independent variable will influence the dependent variable.

Financial Knowledge \&Skills

- Book keeping knowledge

- Business skills

- Financial planning skills

- Credit management skills

- Financial planning skills
Financial sustainability of affirmative

groups

- Repayment duration

- Non-performing loan ratio

- Refinancing

- Own income generation

\subsection{Research Methodology}

\section{Research Design}

This study will use a cross sectional research design. Kothari (2004) describes cross sectional design as fact-finding enquiries, involving asking questions often in the form of a questionnaire of a large group of individuals, adding that the major purpose is description of the state of affairs as it exists at present and represent the findings and information statistically.

\section{Target Population of the Study}

A population has been defined as the total collection of elements about which inferences are made and refers to all possible cases which are of interest for a study (Sekran\&Bougie, 2016).Target population comprises of the groups and the officers in charge with the management the fund at Kapseret Sub County.

Table 3.1: Target Population

\begin{tabular}{lll}
\hline Strata's & Target Population & Percentage \\
\hline Uwezo Fund Groups & 200 & $29.0 \%$ \\
Youth Enterprise Fund Groups & 50 & $39.0 \%$ \\
Women Enterprise Fund Groups & 150 & $32.0 \%$ \\
Total & $\mathbf{4 0 0}$ & $\mathbf{1 0 0 . 0 \%}$ \\
\hline
\end{tabular}

(Source: Kapseret Sub County Headquarters, 2019)

\section{Sampling Size and Sample Technique}

Zikmund, Babin, Carr and Griffin (2010) add that the following factors are required to determine sample size: Heterogeneity of the population, magnitude of the acceptable error and the 
confidence level. The sample size for this research will be obtained using the Yamane's (1967) formula for finite population.

$n=\frac{N}{1+N(e)^{2}}$

Equation 3.1

Where $\mathrm{n}$ is the sample size required

$\mathrm{N}$ is the population size $=400$

$\mathrm{e}$ is the level of precision $=0.05$

$\mathrm{n}=400 / 1+400(0.05)^{2}$

Equation 3.2

$\mathrm{n}=200$

The Sampling frame is shown in Table 3.2.

Table 3.2: Sample Size

\begin{tabular}{clccc}
\hline S/no & \multicolumn{1}{c}{ Strata's } & Population & Percentage & Sample size \\
\hline 1. & Uwezo Fund Groups & 200 & $50 \%$ & 100 \\
2. & Youth Enterprise Fund Groups & 50 & $12.5 \%$ & 25 \\
3. & Women Enterprise Fund Groups & 150 & $37.5 \%$ & 75 \\
Total & & $\mathbf{4 0 0}$ & $\mathbf{1 0 0 . 0 \%}$ & $\mathbf{2 0 0}$ \\
\hline
\end{tabular}

Simple random sampling was used to get samples of the respondents from the different strata. The actual population for data collection was arrived at by using stratified random sampling from each stratum. The stratification was based on Youth enterprise fund, Women enterprise fund and Uwezo enterprise fund groups.

\section{Data Collection Instruments}

The semi structured questionnaire was selected because it is simple to administer and relatively less expensive to analyze (Kothari, 2004). The researchers used this method because questionnaires are free from the biasness. The questions were structured to accommodate both open-ended and closed-ended questions.

\section{Pilot Test}

Pilot test is done to test the efficacy of research instruments and protocols. A pilot study sample should be $10 \%$ of the accessible population (Cann, Connolly, Ruuska, MacNeil, Birmingham, Vandervoort, \& Callaghan, 2008). In this study the pilot study sample size was $10 \%$ of 200 
International Journal of Social Science and Economic Research

ISSN: 2455-8834

Volume:05, Issue:10 "October 2020"

respondents of Moiben Sub County government thus 20 respondents will participate in the pilot study.

\section{Validity of Research Instrument}

This study adopted both content validity and construct validity. Content validity addresses how well the items developed to operationalize a construct provide an adequate and representative sample of all the items that might measure the construct of interest (Mbwesa, 2006). Content validity depended on the judgment of experts in the field, who includes my supervisors since there is no statistical test to determine whether a measure represents a construct or adequately covers a content area.

\section{Reliability of Research Instruments}

This study adopted internal consistency reliability since it is the most commonly used measure of reliability in applied settings. According to Sreevidya and Sunitha (2011) Cronbach' alpha coefficient of above or equal to 0.70 is recommendable for most cases to test reliability.

\section{Data Processing and Analysis}

Data analysis is a mechanism for reducing and organizing data to produce findings that require interpretation by the researcher (Burns \& grove, 2003). Data processing involves translating the answers on a questionnaire into a form that can be manipulated to produce statistics (Hyndman, 2008). It also involves coding, editing, data entry, and monitoring the whole data processing procedure. Questionnaires were used to obtain quantitative data, it was then prepared in readiness for analysis by editing, handling blank responses, coding, categorizing and keyed into statistical package for social sciences version 24.0 for analysis.

Both descriptive and inferential statistics was used in the study. Descriptive statistics will include frequency, percentages, mean and standard deviation. Inferential statistics, mainly Pearson correlation and regression was used. Pearson product moment correlation was used to assess whether there is a significant association between financial sustainability of affirmative groups and financial knowledge and skills as the independent variables. Multiple linear Regression model was used to identify significant predictors of revenue collection. $\mathrm{P}<0.05$ was considered significant. The $\mathrm{P}$ values in the regression coefficient table was used to either accept or reject the null hypothesis; if it is more than 5\% level of significance then the hypothesis was rejected, but if it is less than 5\% level of significance the hypothesis was accepted. The regression model is as follows:

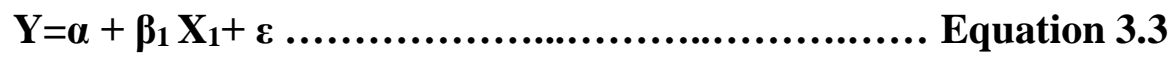

Where:. 
International Journal of Social Science and Economic Research

ISSN: 2455-8834

Volume:05, Issue:10 "October 2020"

Y represents dependent variable (financial sustainability of affirmative groups)

$\boldsymbol{\alpha}$ represents the regression constant. This means Value of $\mathrm{Y}$ when $\mathrm{x}_{1}$ are equal to zero

$\boldsymbol{\beta}_{1}$ represents change in y for each increment change in $\mathrm{x}_{1}$,

$\mathbf{X}_{1}$ represents Financial Knowledge and skills

E represents error term

\subsection{Research Findings and Discussions}

\section{Response Rate}

The number of people who responded to questions were divided by the total number of respondents in the survey. A total of 200 questionnaires were administered. Out of the 200 questionnaires administered, 180 were correctly filled and returned. This represented 90 per cent response rate. Field (2013) hypothesized that a response rate of $75 \%$ is appropriate for analysis. The results for response rate are presented in Table 4.1.

Table 4.1 Response Rate

\begin{tabular}{lll}
\hline Responses & Frequency & Percentage \\
\hline $\begin{array}{l}\text { Administered } \\
\text { questionnaires }\end{array}$ & 200 & 100 \\
Correctly filled and return & 180 & 90 \\
\hline
\end{tabular}

\section{Pilot study Results}

The questionnaire tool was subjected to a pilot study to determine its reliability. The pilot study involved $10 \%$ of the sampled respondents hence 20 respondents were randomly picked from Moiben Sub County government. The pilot results were as follows;

\section{Table 4.2 Reliability Results}

\begin{tabular}{lll}
\hline Objective & Alpha value & Number of items \\
\hline Financial sustainability & 0.783 & 4 \\
Financial knowledge and skills & 0.811 & 4 \\
Repayment plan & 0.702 & 4 \\
Business model & 0.815 & 4 \\
\hline
\end{tabular}


The pilot results indicated that the reliability of the financial sustainability of affirmative groups was 0.783 using Cronbach's alpha test of reliability; the reliability of the financial knowledge and skills was 0.811 ; the reliability of the repayment plan was 0.702 and the reliability of the Business model was 0.815 .

\section{Demographic Information}

Background information is aimed at providing relevant information about the respondents. The study grouped demographic information in terms of gender, age of the respondent and the education level.

\section{Distribution on the Gender of the Respondent}

This study also examined how the affirmative group leaders in KapseretSub County were distributed according to their gender. The results of the analysis are presented in table 4.3.

\section{Table 4.3 Gender of the Respondent}

\begin{tabular}{lll}
\hline Gender & Frequency & Percentage \\
\hline Male & & \\
Female & 120 & 66.7 \\
Total & 60 & 33.3 \\
\hline
\end{tabular}

The study findings on the gender of the respondents showed in Table 4.3 that $66.7 \%$ were male while $33.3 \%$ were female. This shows that most of the affirmative groups' members were male. It also shows that the study managed to minimize the influence of gender biasness by collecting collect data from both genders and their opinions were represented in the study.

\section{Distribution of the Respondents by Age}

The intentions of the study were to find out how the respondents were distributed according to their age bracket. The results were as indicated in the table 4.4.

Table 4.4 Age of the Respondent

\begin{tabular}{lll}
\hline Age bracket & Frequency & Percentage \\
\hline$<20$ years & 5 & 2.8 \\
$20-25$ years & 40 & 22.2 \\
$26-30$ years & 50 & 27.8 \\
$31-35$ years & 65 & 36.1
\end{tabular}


International Journal of Social Science and Economic Research

ISSN: 2455-8834

Volume:05, Issue:10 "October 2020"

$>35$ years

20

11.1

Total

180

100

The study results on the age of the respondents in Table 4.4 indicated that $2.8 \%$ of the respondents were in the age bracket of $<20$ years; $22.2 \%$ were in the age bracket of 20-25 years, $27.8 \%$ were in the age bracket of 26-30 years, $36.1 \%$ were in the age bracket of 31-35 years and $11.1 \%$ were in the age bracket of > 35years. The study results reveal that majority $36.1 \%$ were in the age bracket of 31-35 years while the minorities $2.8 \%$ were less than 20 years old. According to Bass (2015) age brings in experience, responsibility and skill and this was clearly shown from the findings that the majority of the respondents were experienced, responsible and skilled. It also implies that the majority of the respondents were in their mid-thirties.

\section{Academic Qualification}

The qualifications will be based on three levels of academic, certificate, diploma and undergraduate.

\section{Table 4.5 Education Level of the Respondents}

\begin{tabular}{lll}
\hline Education level & Frequency & Percentage \\
\hline Certificate & 30 & 16.7 \\
Diploma & 90 & 50 \\
Undergraduate degree & 60 & 33.3 \\
Total & $\mathbf{1 8 0}$ & $\mathbf{1 0 0}$ \\
\hline
\end{tabular}

The study findings on the education level of the respondents on Table 4.5 indicated that $16.7 \%$ were certificate level, $50.0 \%$ were diploma graduates; $33.3 \%$ had undergraduate. The majority of respondents had a diploma which was a satisfactory level of education that can comfortably facilitate proper understanding of the questionnaire. This implies that the respondents were knowledgeable and therefore understood the study questions and this could be interpreted to mean that they gave a true and fair view of the study questions.

\section{Descriptive Findings and Discussions}

The study examined the views of different respondents on lending conditions on financial sustainability of affirmative groups in Kapaseret Sub County government UasinGishu County. The respondents were requested to indicate their views on a likert scale ranging from:-strongly disagree $=1$, disagree $=2$, undecided $=3$, agree $=4$ and strongly agree $=5$. The frequencies and 
International Journal of Social Science and Economic Research

ISSN: 2455-8834

Volume:05, Issue:10 "October 2020"

percentages of the findings were recorded. The findings were also presented in form of mean, standard deviation and variances.

\section{Effect of Financial Knowledge and Skills on Financial Sustainability}

The first objective of the study was to establish the effect of financial knowledge and skills on financial sustainability of affirmative groups in Kapaseret Sub County government UasinGishu County. The study focused on the book keeping knowledge Business skills, financial planning skills, credit management skills. The researcher was interested with the opinions of the respondents on the extent to which such constructs affect financial sustainability. The study findings were as tabulated in 4.6.

Table 4.6 Effect of Financial Knowledge and Skills on Financial Sustainability

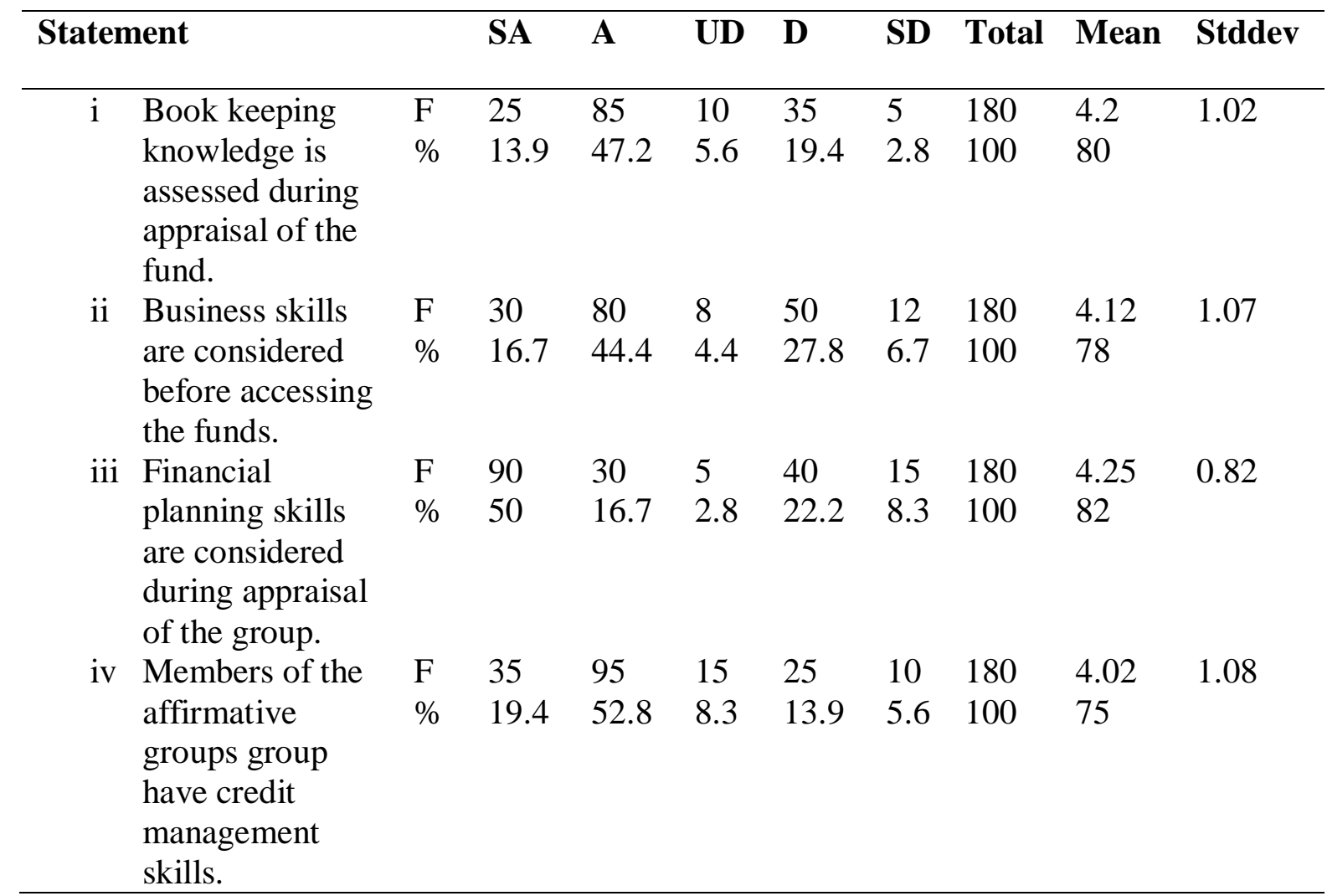

The study findings as shown in Table 4.6, revealed that $61.1 \%$ of the respondents agreed that book keeping knowledge is assessed during appraisal of the fund as compared to $22.2 \%$ who disagreed( Mean $=4.20: \mathrm{SD}=1.02$ ). These findings were supported by Silva (2012) who noted that keeping sound book keeping records adds to more elevated amounts of money related to maintainability and consequently a positive relationship. 


\section{International Journal of Social Science and Economic Research}

ISSN: $2455-8834$

Volume:05, Issue:10 "October 2020"

The respondents were also requested to give their views on whether business skills are considered before accessing the funds. The study results as shown in Table 4.6 that $61.1 \%$ agreed that business skills are considered before accessing the funds with a (Mean $=4.12$ : SD $=1.07$ ) as compared to $34.5 \%$ disagreed. This was in agreement with findings by Pimpong and Laryea (2016) who revealed that book keeping knowledge is assessed during appraisal of the fund. Business skills provide useful information for superiors to evaluate group performance and inform cash allocation strategies across various components of a group. The study found out that business skills had a strong positive effect on loan repayment because of financial knowledge and financial information management. Business skills are effective in ensuring timely repayments of funds, instilling supervision and administration traits among the group member.

In addition, the respondents were asked if financial planning skills are considered during appraisal of the group and the study findings revealed that $66.7 \%$ of the respondent agreed that financial planning skills are considered during appraisal of the group with a (Mean $=4.25 ; \mathrm{SD}=$ 0.82), compared with $30.5 \%$ who disagreed. The research findings were in agreement with Lilay, Desta and Wondmagegn (2015) who researched on the effect of financial knowledge on financial sustainability of affirmative groups' in Ethiopia and found that financial knowledge had a significant effect on financial sustainability of affirmative groups in Ethiopia.

Moreover, the study results on Table 4.6 shows that $72.2 \%$ of the respondents agreed respectively that members of the affirmative groups have credit management skills with a (Mean= $4.02 ; \mathrm{SD}=1.08$ ), while $19.5 \%$ disagreed.These results were in agreement with results by Mwangi and Wekesa (2015) who observed that credit management skills influences financial management of a firm. The study revealed that the relationship between credit management skills and financial sustainability was statistically significant. Majority of affirmative groups used a combination of both top-down and bottom-up approach when preparing budgets. The affirmative groups prepare annual budgets covering 12 months. Majority of affirmative groups involve the heads of various departments, managing directors and administrative heads.

\section{Financial Sustainability of Affirmative Groups}

The study finally sought to determine the indicators of financial sustainability of affirmative in Kapseret Sub-County, UasinGishu County. The study results were as tabulated in Table 4.7.

Table 4.7 Financial Sustainability of Affirmative Groups

\begin{tabular}{cllllllllll}
\hline Statement & & & SA & A & UD & D & SD & Total & Mean & $\begin{array}{l}\text { Std.de } \\
\mathbf{v}\end{array}$ \\
\hline i & $\begin{array}{l}\text { The amount is repaid } \\
\text { within one year. }\end{array}$ & F & 65 & 95 & 12 & 8 & 0 & 180 & 4.50 & 0.765 \\
& & & 36.1 & 52.8 & 6.7 & 4.4 & 0 & 100 & 90.4 &
\end{tabular}


International Journal of Social Science and Economic Research

ISSN: 2455-8834

Volume:05, Issue:10 "October 2020"

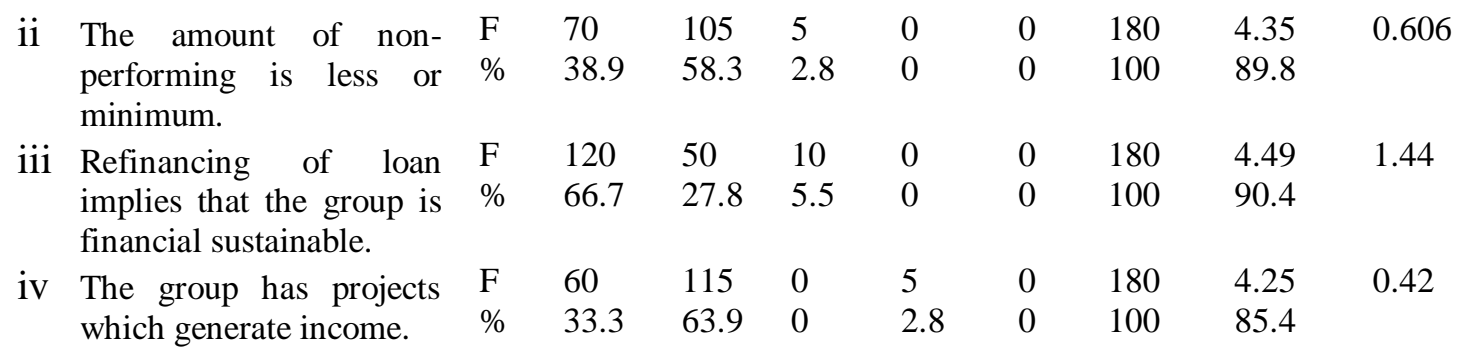

The study results on Table 4.7 indicators of financial sustainability revealed that $88.9 \%$ agreed with a (mean $=4.50 ; \mathrm{SD}=0.765)$ were of the view that the amount is repaid within one year. Those of the $97.2 \%$ agreed were of the view that the amount of non-performing is less or minimum with a (mean $=4.35 ; \mathrm{SD}=0.606$ ). The respondents with $94.5 \%$ agreed were of the view that refinancing of loan implies that the group is financial sustainable with a (mean= 4.49; $\mathrm{SD}=1.44)$.The respondents that were of the view that the group has projects which generate income were $97.2 \%$ agreed, with a (mean $=4.25 ; \mathrm{SD}=0.42)$.

Repayment of the fund by the groups will make funds to be available for others to benefit from it too. According to the Auditor general's report (2017), the affirmative groups have not reached the targeted number of groups despite a disbursement of more than Sh7 billion. The report further indicated that regardless of the many groups that received soft loans from either the youth enterprise fund, women enterprise fund or the Uwezo Fund many have defaulted on paying back the amounts within stipulated time or failed to pay thus inhibiting sustainability of the affirmative groups (Bwayo, 2017).

\section{Multiple Regression Model Analysis}

The study performed multiple regression model analysis to estimate the relationships between the study variables. The study results were as tabulated in Table 4.8.

Table 4.8 Model Summary

\begin{tabular}{lllll}
\hline $\begin{array}{l}\text { Mode } \\
\mathbf{l}\end{array}$ & R & R Square & Adjusted R Square & $\begin{array}{l}\text { Std. Error of the } \\
\text { Estimate }\end{array}$ \\
\hline 1 & $.836^{\mathrm{a}}$ & .823 & .868 & .01868 \\
\hline
\end{tabular}

Predictors: (Constant), financial knowledge and skills

From the table 4.13 above, $\mathrm{R}$-square is used to evaluate the best fit of a model. $\mathrm{R}$ square coefficient of determination is the statistical measure of how well the regression line approximates the real data. It measures the proportion of the variation in dependent variable. $\mathrm{R}-$ 
International Journal of Social Science and Economic Research

ISSN: 2455-8834

Volume:05, Issue:10 "October 2020"

is the multiple correlation coefficients which was 0.836 considered as one of the measure of the quality of prediction of the dependent variable (financial sustainability) in the study. This indicated a strong correlation between the independent variables and the dependent variables. $\mathrm{R}^{2}$ being the coefficient of determination at 0.823 which gives the proportion of variance in the dependent variable that is explained by the independent variables. As such the findings showed that the independent variables taken together accounted for only $82.3 \%$ of the total variance in sustainable revenue collection. The adjusted R-squared is a modified version of R-squared that has been adjusted for the predictor in the model which shows variation of financial knowledge of 0.868 of the financial sustainability. The standard error of the estimate of $s=0.01868$ ) which is $1.868 \%$ which indicates how the regression model is using the units of the dependent variable.

\section{Assessing the Fit of the Multiple Regression Model}

Analysis of variance (ANOVA) was employed to measure the differences in means between financial sustainability and its predictor variables. The results are shown in Table 4.9.

Table 4.9 ANOVA Model

\begin{tabular}{llccccc}
\hline Model & & $\begin{array}{c}\text { Sum of } \\
\text { Squares }\end{array}$ & df & $\begin{array}{c}\text { Mean } \\
\text { Square }\end{array}$ & F & Sig. \\
\hline $\mathbf{1}$ & Residual & 111.32 & 4 & 25.015 & 99.676 & $0.000^{\mathrm{b}}$ \\
& Regression & 9.232 & 61 & 0.0898 & & \\
& Total & $\mathbf{1 2 0 . 5 5 2}$ & $\mathbf{6 5}$ & & & \\
\hline
\end{tabular}

The linear regression's F-test has the null hypothesis that the model explains zero variance in the financial sustainability $\left(\mathrm{F}=99.676, \mathrm{p}=0.000^{\mathrm{b}}\right)$. The F-test is highly significant, thus it is assumed that the model explained a significant amount of the variance in financial sustainability. This implies that the multiple regression model was fit for the data and hence financial knowledge and skills affect financial sustainability.

The study results further revealed that the model summary predicted financial sustainability of affirmative groupssignificantly well $(\mathrm{p} \leq 0.05)$. This indicated the statistical significance of the regression model that was run and that overall the regression model statistically significantly predicted the financial sustainability of affirmative groups(that is, it was a good fit for the data).

\section{Regression Coefficients}

T-test of statistical significance of each regression coefficient was conducted in order to determine the beta which indicates how strongly each independent variable affects the dependent variable. The study results were shown in Table 4.9. 
International Journal of Social Science and Economic Research

ISSN: $2455-8834$

Volume:05, Issue:10 "October 2020"

Table 4.9 Regression Coefficient

\begin{tabular}{|c|c|c|c|c|c|}
\hline \multirow[t]{2}{*}{ Model } & \multicolumn{2}{|c|}{$\begin{array}{l}\text { Unstandardized } \\
\text { Coefficients }\end{array}$} & \multirow{2}{*}{$\begin{array}{c}\text { Standardized } \\
\text { Coefficients } \\
\text { Beta }\end{array}$} & \multirow[t]{2}{*}{$\mathrm{t}$} & \multirow[t]{2}{*}{ Sig. } \\
\hline & B & Std. Error & & & \\
\hline (Constant) & 0.369 & 0.224 & & 1.648 & 0.105 \\
\hline Financial knowledge & 0.170 & 0.024 & 0.319 & 6.604 & 0.000 \\
\hline
\end{tabular}

Dependent Variable: financial sustainability

From the regression equation, payment option measures were the most important variable to financial sustainability of affirmative groups contributing $26.3 \%$ to financial sustainability of affirmative groups while financial knowledge and skills measures contributed 17.0\%, repayment plan measures contributed $23.1 \%$ and Business model measures contributed $21.3 \%$ to financial sustainability of affirmative groups.

The regression equation further revealed that there was a significant relationship between financial knowledge and skills and financial sustainability of affirmative groups $(\beta=0.170$, $\mathrm{p} \leq 0.05)$.

\section{Regression Model}

The regression function in equation 4.1 was used to explain the results of the regression model analysis.

$\mathrm{Y}=\mathbf{0 . 3 6 9}+\mathbf{0 . 1 7 0} \mathrm{X}$ Equation 4.1

The financial knowledge and skills measures coefficient parameter is 0.170 meaning that for every adjustment in one unit of Repayment plan would result in a 0.170 change in financial sustainability of affirmative groups while all other variables are kept constant.

\section{Hypothesis Test Results}

The research aimed to test the hypothesis with an aim of failing to reject or rejecting the relationship between independent and the dependent variables. The research hypothesis for the study included;

$\mathbf{H}_{01}$ : Financial knowledge and skills measures have no significant effect on financial sustainability of affirmative groups.The study findings indicated that there was a statistical significant relationship between financial knowledge and skills measures and financialsustainability of affirmative groups. $\beta=0.170, p \leq 0.05$ ). The study therefore rejected the null hypothesis and accepted the alternate hypothesis which showed that there was a relationship between financial knowledge and skills and financial sustainability of affirmative groups. The 


\section{International Journal of Social Science and Economic Research}

ISSN: $2455-8834$

Volume:05, Issue:10 "October 2020"

study findings concur with study done by Postelnicu, Hermes, and Servin (2019) examined external social ties and loan repayment of group lending members of Pro Mujer in Mexico.

The study aimed at establishing whether external social ties had effect on loan repayment. The resources in external ties were measured in conditions of the informal risk insurance arrangement they embed. The extent to which social networks of group members are overlapping is used to extend external ties as collateral. Further, the more borrowers' networks of external ties overlap, the higher the risk of losing the informal risk insurance arrangement in case of non-repayment. The study found that group borrowers with external ties, representing a strong informal risk insurance arrangement while at the same time being information channels, have lower repayment problems. Emphasis was not put on the essence of business skills that group members should possess which the current study seeks to incorporate. Milgo (2012) assessed the effect of book keeping skills on loan repayments of Youth Enterprise Fund in Kenya.

The objective of this study was to establish the effect of book keeping skills on loan repayment rates of youth enterprise fund in Kenya. A causal research design was adopted in the study. The study found out that book keeping skills had a strong positive effect on loan repayment because of financial knowledge and financial information management. Book keeping skills is effective in ensuring timely repayments of funds, instilling supervision and administration traits among the group members.

The findings could not agree by Lilay, Desta and Wondmagegn (2015) researched on the effect of financial knowledge on financial sustainability of affirmative groups' in Ethiopia. The aim of this study was to identify and analyze whether financial knowledge had effect on the financial sustainability of affirmative groups in Ethiopia. This study applied explanatory research approach, cross-sectional primary data, stratified sampling techniques and finally employed chisquare test to test the association of the independent variables and loan repayment sustainability. The researchers found that financial knowledge had a significant effect on financial sustainability of affirmative groups in Ethiopia.

\subsection{Summary of the Findings, Conclusion and Recommendation}

\section{Summary of Findings}

This study was designed to find out the effect of financial knowledge and skills on financial sustainability of affirmative groups in Kapseret Sub County, UasinGishu County. The objective of the study sought to examine the effect of financial knowledge and skills financial sustainability of affirmative groups in Kapseret Sub County. The study indicated that there was a significant relationship between financial knowledge and skills and financial sustainability of affirmative groups. This implied that financial knowledge and skills is a factor for financial 


\section{International Journal of Social Science and Economic Research}

ISSN: $2455-8834$

Volume:05, Issue:10 "October 2020"

sustainability of affirmative groups in Kapseret Sub County.These findings meant that the null hypothesis was rejected.

\section{Conclusion of the Study}

Based on the study findings the study concludes as follows;

Financial knowledge and skills affect financial sustainability of book keeping knowledge this is assessed during appraisal of the fund, having sound book keeping records adds to more elevated amounts of money related to maintainability and consequently a positive relationship. Business skills provide useful information for superiors to evaluate firm performance and inform cash allocation strategies across various components of a firm. They are effective in ensuring timely repayments of funds, instilling supervision and administration traits among the group member, financial planning skills are considered during appraisal of the group, financial knowledge was found to have a significant effect on financial sustainability of affirmative group, credit management skills influences financial management of a firm.

The members of the affirmative groups should enhance the knowledge and skillsto improve financial sustainability.

\section{Recommendation of the Study}

Based on the study findings and conclusion;

The Policy and practice recommendation are that the government affirmative action Oversight Board should identify and engage the stakeholders more to harmonize its goals and objectives with the aspirations of the stakeholders and reduce dissonance levels thereby increasing satisfaction and ownership. This will ensure that the stakeholders support the activities of the affirmative group projects. This study recommends that the management of the affirmative groups to ensure that their organizations have appropriate financial knowledge and skills that will ensure that the business thrives, the uncalculated skills are the business skills, financial planning skills and credit management skills as this will help prevent all financial risks and misappropriation of funds. These skills will ensure that loan processes are valid and have been verified before the disbursement of funds.

Should contributes to the knowledge in the sustainability of affirmative groups from internal sources of funds, hence support vision 2030. Sustenance of affirmative groups would widen inclusion in financial sector. The poor who have all through been ignored and excluded in financial services will get a chance to participate in financial services. They will have the opportunity to have access to finance.

\section{Suggestion for further Studies}




\section{International Journal of Social Science and Economic Research}

ISSN: $2455-8834$

Volume:05, Issue:10 "October 2020"

This study focused on the effect of lending conditions on financial sustainability on affirmative groups. The researcher suggests that a further research to be done on the same area but focusing on other variables of financial sustainability not included in the current study. This study further suggests that a research need to be done on the same area but on challenges facing lending conditions on financial sustainability. Finally, the study suggests that further research need to be conducted to determine other lending conditions that affect financial sustainability in sub county governments.

\section{References}

Armendariz, B., \&Morduch, J. (2005).The Economics of Microfinance.The Economic Journal, 8 (3), 278- 284.

Asgedom, A.K., Desta, S.T., \&Bahita, G.H. (2015). Group Lending Factors Affecting Group Loan Repayment Sustainability Of Government Based Loans in Mekelle, Ethiopia. Journal of Poverty, Investment and Development, 10(2), 21 - 43.

Ayogyam, A., Mohammed, H., Goddana, M. D., \&Boateng, E. (2014). Monitoring Loan Repayment Among Farmers in Techiman, Ghana: Investigating The Effect of Cooperative Farming System. Journal of Emerging Trends in Economics and Management Sciences, 5(1), 32-37.

Bwayo, P. (2017). Most Uwezo Fund Group Borrowers Have Defaulted, Ps Says.Applied Economics, 44(26), 3421-3433.

Cann, A. P., Connolly, M., Ruuska, R., Macneil, M., Birmingham, T. B., Vandervoort, A., \& Callaghan, J. P. (2008). Inter-Rater Reliability of Output Measures for Posture Matching Assessment Approach:Journal of Development Economics 60, No. 1 (1999): 51-77.

De Aghion, B. A. (2009). On The Design of A Credit Agreement With Peer Monitoring. Journal of Development Economics, 60(1), 79-104.

Lilay, D., \&Wondmagegn (2015). Micro, Small and Medium Enterprise Growth and Innovation In Kenya: A Case Study on The Women Enterprise Fund. Investment Climate and Business Environment Research Fund, 2(1),1-104.

Ghatak, M. (2000). Screening By The Company You Keep: Joint Liability Lending and The Peer Selection Effect. The Economic Journal, 110(465), 601-631.

Hermes, \&Servin (2019). Peer Monitoring, Social Ties and Moral Hazard in Group Lending Programs: Evidence From Eritrea. World Development, 33(1), 149-169. 


\section{International Journal of Social Science and Economic Research}

ISSN: 2455-8834

Volume:05, Issue:10 "October 2020"

Hermes, N., Lensink, R., \&Mehrteab, H. T. (2005).Peer Monitoring, Social Ties and Moral Hazard in Group Lending Programs: Evidence From Eritrea. Journal of Development Economics, 60(1), 51-77.

Karlan, D., \&Morduch, J. (2009).Access to Finance Chapter 2. Journal of International Development, 8(2), Pp.145-152.

Kombo, D. K., \& Tromp, D. L. (2009). Introduction to Proposal Writing (2 ${ }^{\text {nd }}$ Ed.).Nairobi: Pauline Publications.

Kothari C.R. (2004). Research Methodology: Methods and Techniques (3rd Ed.). New Dheli: New Age International Publishers.

Laffont, J. J. (2013). Collusion and Group Lending with Adverse Selection. Journal of Development Economics, 70(2), 329-348.

Laffont, J. J., \& Rey, P. (2000).Collusion and Group Lending with Moral Hazard", Mimeo Idei.Journal of Development Economics, 15(1), 179- 188.

Lilay, W. L., Desta, T. S., \&Wondmagegn, G. A. (2015). Determinants of MFIS Group Loan Repayment Sustainability: A Case of Mses' Service Sector in Mekelle City, Ethiopia. International Journal of Economics and Finance, 4 (1), 51 - 60.

Million, S., Nyikal, R., \&Wania, S. (2012). Factors Affecting Loan Repayment Sustainability Journal of Operational Research 234, No. 1 (2014): 319-330.

Mugenda, O. M., \&Mugenda, A. G. (2003).Research Methods: Quantitative and Qualitative Approaches ( $2^{\text {nd }}$ Ed.). Nairobi, Acts Press.

Muthoni (2016), The Growth of Small Enterprises: Towards A Research Agenda, American Journal of Economics and Business Administration, 8 (13), 230-278.

Muli, D.K. (2016). Effect of Repayment Plan on The Sustainability of Youth Enterprise Development Fund Loans in Coast Region in Kenya. Journal of Development Economics, 14(1), 27-33.

Mungai, J. N. (2015). Loan Repayment and Sustainability of Government Vulnerable Funds in Murang'a County, Kenya.Unpublished Master Thesis, Kenyatta University, Nairobi, Kenya.

Mbwesa, J. K. (2006). Introduction to Management Research. A Student Handbook: $\quad$ (2 ${ }^{\text {nd }}$ Ed.). Nairobi: Basic Modern Management Consultants.Nakuru, V. (2014). Mp Calls For 


\section{International Journal of Social Science and Economic Research}

ISSN: $2455-8834$

Volume:05, Issue:10 "October 2020"

Consolidation of Uwezo and Women Funds.Journal of Finance, Accounting And Management, 10(1), 43-56.

Newing, R. (2011). Environment: Long-Term Impact of Green Issues Played Down. International Journal of Economics and Finance, 3 (1), 9 - 17.

Njuguna, C.W. (2014). Factors Influencing Sustainability of Vulnerable Loan Fund Programmes: A Case of Women Groups in Kikuyu District, Kiambu County, Kenya.Journal of Applied Corporate Finance, 3(2), 111- 119.

Oboh, V. U., \&Ekpebu, I. D. (2011). Determinants Of Formal Agricultural Credit Allocation To The Farm Sector By Arable Crop Farmers in Benue State, Nigeria. African Journal of Agricultural Research, 6(1), 181-185.

Odour, S. (2019, April).Tana River Shut Out Of Uwezo Fund Over Default.Journal of International Development, 8(2), Pp.135-132.

Olima, G. A. (2016). Influence Of Uwezo Funds on Enhancing Livelihoods Among Youth and Women in Ainabkoi Sub County, UasinGishu County, Kenya.Moi University, Eldoret, Kenya.

Otieno, A.G. (2014). Factors Influencing Sustainability of the Uwezo Fund Assisted Youth Projects in Migori County, Kenya.Journal of Finance, 7 (3), 183- 190.

Postelnicu, L., Hermes, N., \&Servin, R. (2019). External Social Ties and Loan Repayment of Group Lending Members: A Case Study of Pro Mujer Mexico. The Journal of Development Studies, 55(8), 1784-1798.

Quinlan, C. (2011). Business Research Methods.Hampshire, Uk: Journal of International Development, 8(2), Pp.145-152.

Reavley, M. A., \&Lituchy, T. R. (2008). Successful Women Entrepreneurs: A Six- Country Analysis of Self-Reported Determinants of Success-More Than Just Dollars and Cents. International Journal of Entrepreneurship and Small Business, 5(3), 272 - 277.

Sagwe, J., Gacheru, S., \&Mahea, T. (2011). Youth and Women Enterprises Reparedness in Kenya. Journal of Finance, 30 (1), 211- 217.

Saunders, M. N. (2012). Choosing Research Participants. Qualitative Organizational Research: Core Methods and Current Challenges, 12(2), 35-52.

Sreevidya, L. \&Sunitha, W. (2011). Capital Structure and The Information Role of Debt. Journal of Finance, 45 (5), 321-349. 
International Journal of Social Science and Economic Research

ISSN: 2455-8834

Volume:05, Issue:10 "October 2020"

Udoh, E. J. (2018). Estimation of Loan Default Among Groups of A State Government Owned Agricultural Loan Scheme, Nigeria. Journal of Central Europea Agriculture, 9(2), 343-352.

Van Tassel, E. (2009). Group Lending Under Asymmetric Information. Journal of Development Economics, 60(1), 3-25.

Wilson, R. \&Lituch (2008), Social Connections and Group Banking. The Economic Journal, 117(517), 52-84

World Bank.Afthd.,\& World Bank. Decrg. (2009). Causes Of Default on Micro-Credit Among Women Micro Entrepreneurs in Kenya.A Case Study of Women Enterprise Development European Journal of Operational Research.2014; ;234(1):319-30.

Fund (Wedf) Msambweni Sub County. Iosr Journal Of Economics and Finance, 3(6), 32-47.

Wheelan, S. A. (2009). Group Size, Group Development, and Group Productivity. Small Group Research, 40(2), 247-262.

Zikmund, G. W., Babin, J. B., Carr, C. J., \& Griffin, M. (2010).Applied Economics, 44(26), 3421-3433. 